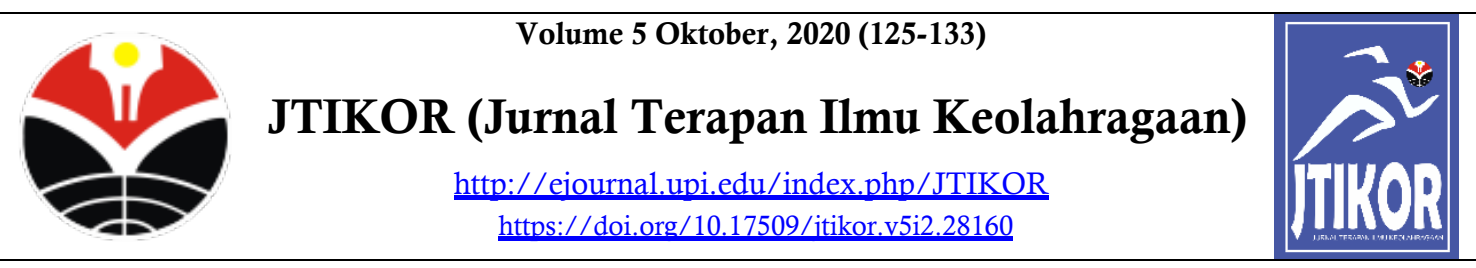

\title{
Tingkat Persepsi dan Ketertarikan Masyarakat Dalam Aktivitas Fisik Berirama Dalam Menjaga Kebugaran Fisik
}

\author{
Firdaus Hendry Prabowo Yudho $\bowtie$, Adi Rahadian, Mela Aryani, Asep Ramdan \\ Afriyuandi , Andi Kurniawan Pratama
}

Pendidikan Jasmani, Universitas Suryakancana, Indonesia

\begin{tabular}{l} 
Info Artikel \\
\hline Kata Kunci: \\
Aktivitas Fisik, Aktivitas Ritmik, \\
Persepsi Komunitas, Senam \\
Kesegaran Jasmani. \\
Keywords: \\
Community Perception, Fitness \\
Exercise, Physical Activity, Rhythmic \\
Activity \\
\hline$\square$ Komplek Bumi Asri Kebon \\
Jeruk, Blok C-17, Cilaku, Cianjur \\
- 43285 \\
E-mail: \\
firdaus hendri@unsur.ac.id \\
\hline
\end{tabular}

\begin{abstract}
Abstrak
Penelitian ini dilatar belakangi oleh masih sedikitnya informasi mutakhir akan persepsi dan ketertarikan masyarakat untuk melakukan aktivitas gerak olahraga umum dan aktivitas gerak berirama. Tujuannya adalah untuk mendapatkan informasi mengenai tingkat persepsi masyarakat terhadap aktivitas fisik berirama dalam rangka menjaga kebugaran fisik yang mereka miliki. Penelitian menggunakan metode survei untuk 5 kategori aktivitas ritmik yang popular di masyarakat, yakni Senam SKJ, Aerobik Low Impact, Aerobik High Impact, Senam Jantung Sehat/ Lansia, Zumba, dan Senam Dangdut dengan sampel sebanyak 193 orang. Data sampel diperoleh dengan metode survei instrument angket daring untuk kemudian di analisis dengan menggunakan analisis statistika deskriptif. Kesimpulan dari penelitian ini mengungkap tingkat ketertarikan yang cukup daripada masyarakat terhadap aktivitas Ritmik sebagai salah satu kegiatan yang menarik untuk menjaga kebugaran tubuh dengan hasil rata-rata responden perempuan relatif lebih menyukai aktivitas ritmik secara umum dibanding laki-laki..
\end{abstract}

\section{Abstract}

This research is motivated by the lack of up-to-date information on people's perceptions and interests in general sports and rhythmic movement activities. The aim is to obtain information about the level of public perception of rhythmic physical activity to maintain physical fitness. The study used a survey method for five categories of popular rhythmic activities in the community, namely SKJ, Low Impact Aerobics, High Impact Aerobics, Healthy Heart Exercises / Elderly, Zumba, and Dangdut Gymnastics, with a sample of 193 people. Online survey methods obtained the sample data, and the data were analyzed using descriptive statistics. This study's conclusion reveals a sufficient level of public interest in rhythmic activities as an interesting activity to maintain body fitness. The average result that female respondents prefer rhythmic activities in general compared to males. 


\section{PENDAHULUAN}

Masyarakat yang bugar dan aktif merupakan keinginan ideal yang selalu menjadi tujuan utama yang dimiliki oleh suatu negara. Dengan masyarakat yang memiliki tingkat kebugaran dan keaktifan secara fisik yang baik akan berkaitan dengan tingkat produktivitas dan kesejahteraan yang dimiliki oleh masyarakat di negara tersebut. Hal ini pun sesuai dengan tujuan utama kementerian kesehatan Republik Indonesia 2015-2019, "Merealisasikan Negara Indonesia yang berdaulat, bebas, berkarakter kuat dan bergotong royong sebagai landasan utamanya" (Ministry of Health Republic of Indonesia, 2013). Terdapat dua tujuan utama yang ingin dicapai dalam rencana dan strategi Kementerian Kesehatan sendiri, yakni 1) Peningkatan status kesehatan masyarakat; 2) Peningkatan respon sosial dan perlindungan keuangan masyarakat di sektor kesehatan. Berdasarkan hal ini peneliti kemudian melaksanakan penelitian yang berkaitan dengan persepsi dan ketertarikan masyarakat terhadap aktivitas fisik secara umum dan aktivitas ritmik sebagai salah satu pilihan aktivitas yang dapat dilakukan dengan mudah, murah dan masif. Hal ini senada dengan salah satu upaya yang dilakukan oleh kementerian kesehatan dalam salah satu poin strategi kebijakannya yakni "to drive community empowerment" dalam bidang kesehatan (Ministry of Health RI, 2018), dan juga rekomendasi yang diberikan oleh WHO mengenai pentingnya aktivitas fisik yang berkaitan dengan tingkat rentang usia (anakanak, remaja, dewasa, dan manula) (WHO, Strategy, Diet, \& Activity, 2007).

Terkait dengan bidang olahraga sendiri, Kementerian Pemuda dan Olahraga telah menerbitkan kebijakan yang tertuang dalam rencana dan strateginya yakni meningkatkan budaya olahraga dan gaya hidup sehat di kalangan masyarakat untuk kebugaran dan produktivitas (Nahrawi, 2017). Budaya serta kebiasaan berolahraga sendiri dapat terjadi dan terwujud dengan baik jika ada beberapa hal yang mendukung terjadinya hal tersebut, salah satunya adalah peran para peneliti dan lingkungan akademik perguruan tinggi yang mampu menjawab fenomena di masyarakat dalam berkaitan dengan keinginan dan persepsi masyarakat dalam memiliki pola hidup bugar dan sehat. Sebagai contoh kasus dimana kondisi social remaja dan anak-anak di Indonesia saat ini sudah banyak yang terbiasa merokok dalam kehidupan sehari-harinya (Yudho, Taufik, \& Afriyuandi, 2020), memunculkan ide dan gagasan untuk meminimalisir dampak negative dari hal tersebut. Sebagai salah satu ide yang berkaitan dengan penanggulangan kondisi social dalam beraktivitas fisik, maka diperlukan pengetahuan mengenai persepsi masyarakat terhadap aktivitas fisik yang biasa dilakukan sehari-hari. Persepsi sendiri memiliki arti pengamatan secara sadar yang dilakukan seseorang sebagai landasan untuk menerima ideide baru (K. B. I. Penyusun, n.d.). Dalam menentukan data yang diperoleh dalam kuesioner, peneliti membagi responden yang dituju ke dalam tiga bagian rentang usia yang terdapat dalam panduan World Health Organization (WHO) yakni usia 5-17 tahun, 1864 tahun, dan 65 tahun keatas (World Health Organization, 2020).

Aktivitas ritmik sendiri menjadi salah satu aktivitas yang sangat penting untuk dilakukan semua orang, terutama dalam masa kanak-kanak hingga remaja (Lin, 2014). Dengan adanya beberapa penelitian yang menyebutkan bahwa terdapat efek yang positif dari penggunaan musik dalam kegiatan olahraga dan latihan fisik (Lykesas, Dania, Koutsouba, \& Nikolaki, 2017). Selama dua dekade terakhir, musik telah menjadi hampir di mana-mana di tempat-tempat yang terkait dengan latihan fisik, pelatihan olahraga atau kompetisi. Ini dimainkan di gimnasium, stadion atletik dan bahkan melalui speaker bawah air di kolam renang (Lane, 2008).

Departemen Kesehatan dan Layanan Kemanusiaan di pada tahun 2008 merekomendasikan anak-anak dan remaja untuk aktif secara fisik setidaknya 60 menit setiap hari dan harus berpartisipasi dalam kegiatan yang kebanyakan intensitasnya sedang hingga kuat, dan penguatan otot dan tulang. Pendidikan Jasmani adalah landasan bagi upaya 
sekolah yang komprehensif untuk meningkatkan tingkat aktivitas fisik siswa, (Stott, 2013). Hal ini juga tidak terlepas dari kepercayaan diri yang dimiliki oleh para siswa dalam menerapkan keterampilan yang dilakukan dan sisanya $71 \%$ dipengaruhi oleh faktor lain (Yudho, 2016).

Gambar 1: Konsep dari keuntungan penggunaan musik dalam olahraga dan latihan fisik

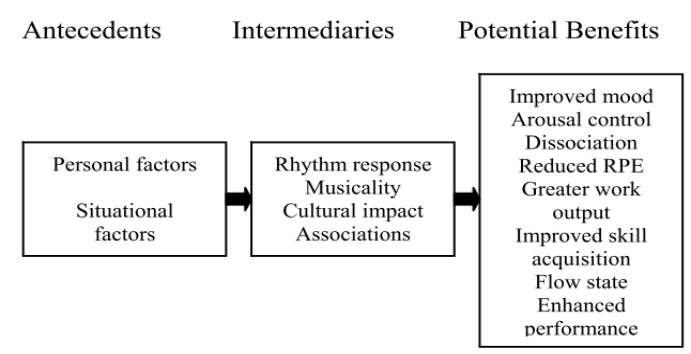

Sumber: Terry \& Karageorghis (2006).

Aktivitas Ritmik sendiri merupakan rangkaian gerak manusia yang dilakukan dalam ikatan pola irama, disesuaikan dengan perubahan tempo atau semata-mata gerak ekspresi tubuh mengikuti iringan musik atau ketukan di luar musik. Kesesuaian antara gerakan tubuh dengan irama sangat diutamakan dalam aktivitas Ritmik, (Suharjana, 2010). Menurut penelitian yang sama terungkap bahwa kehadiran aktivitas ritmik dalam kurikulum pendidikan jasmani di sekolah dasar perlu direspon secara positif oleh guru-guru pendidikan jasmani. Sebelum ada istilah aktivitas ritmik, sudah ada istilah senam irama tetapi hanya sebatas pada gerak senam yang diiringi oleh irama. Penelitian yang lain menyebutkan bahwa penggunaan musik yang sinkron melibatkan melakukan gerakan berulang dalam waktu dengan elemen ritmisnya seperti ketukan atau tempo. Komposisi musik sendiri mensyaratkan pengorganisasian tiga elemen utama, yakni: Melodi, harmoni dan ritme. Melodi adalah irama musik - bagian yang bisa Anda bersenandung atau bersiul; harmoni bertindak untuk membentuk suasana musik untuk membuat Anda merasa bahagia, sedih, tegang atau romantis melalui jalinan suara; sedangkan ritme berkaitan dengan kecepatan musik dan cara aksennya (Lane, 2008). Salah satu contoh paling jelas dari manfaat musik sinkron dalam olahraga diamati ketika atlet Ethiopia, Haile Gebreselassie, memecahkan rekor lari indoor 2000 meter pada tahun 1998 sambil menyinkronkan laju langkahnya ke lagu pop berirama Scatman (Terry \& Karageorghis, 2006). Meskipun demikian, terdapat penelitian lainnya yang mengungkap ketidak tertarikan remaja terhadap olahraga maupun musik sebagai mata pelajaran yang di minati dimana sampel remaja pria lebih tertarik untuk mendaftar dalam olahraga elektif daripada dalam musik, dengan $42,7 \%$ memilih olahraga elektif dan hanya 4,8\% memilih musik. Namun, hampir setengah dari peserta $(49,8 \%)$ tidak memilih musik atau olahraga sebagai salah satu mata pelajaran sekolahnya (Waters \& McPherson, 2014). Hal lainnya terungkap dalam penelitian lainnya yang menyebutkan bahwa nilai rerata kemampuan gerak sampel perempuan lebih baik dibandingkan sampel pria hingga 10\% (Yudho, 2018). Penelitian sebelumnya menunjukkan bahwa seseorang yang memiliki tingkat kebugaran jasmani yang tinggi akan memiliki kekuatan dan ketahanan untuk melakukan aktifitas kehidupan tanpa mengalami kelelahan yang berarti, dan hal ini salah satunya dapat dilakukan dengan metode aktivitas Senam Kesegaran Jasmani, dimana Senam SKJ 2008 berpengaruh signifikan terhadap peningkatan kebugaran jasmani siswi Sekolah Dasar (Lucy Oktavani, 2017), senam irama lagu gizi seimbang berpengaruh terhadap tingkat kebugaran fisik (Juliasti, Kuswari, \& Jus'at, 2020), dan latihan khususnya daya tahan kardiorespirasi bagi tubuh lebih baik menggunakan senam aerobik Mix Impact (Soraya, 2012).

Adapun penelitian ini dilakukan untuk mengungkap persepsi dan ketertarikan masyarakat terhadap beberapa aktivitas ritmik yang sudah dilakukan secara umum yakni aktivitas Senam Kesegaran Jasmani, Senam Aerobic Low-Impact, Senam Aerobic HighImpact, Senam Jantung Sehat/ Lansia, Zumba dan Senam Dangdut. Dengan adanya informasi 
lebih lanjut mengenai persepsi masyarakat akan memberikan informasi lebih lanjut bagi berbagai pihak untuk menentukan strategi aktivitas fisik berbasis kegiatan ritmik yang baik kepada masyarakat dalam semua tingkatan usia dan klasifikasi sosial. Hal ini juga barang tentu akan memberikan kontribusi yang baik dalam peningkatan aktivitas jasmani masyarakat secara individu maupun secara massal dengan adanya pemetaan segmentasi persepsi masyarakat dalam menentukan aktivitas ritmik yang sesuai dengan karakteristiknya masingmasing dan untuk kedepannya dapat dibuat suatu strategi dan metode yang tepat dalam mengolahragakan masyarakat sesuai dengan persepsi dan kesukaan mereka akan aktivitas ritmik tertentu.

\section{METODE}

Penelitian ini menggunakan pendekatan kuantitatif dengan metode survey, sementara instrument alat pengumpul data yang digunakan adalah kuesioner teknik survey. Kuesioner yang digunakan menggunakan media google form free edition dengan populasi yang di tuju sebagai target penelitian adalah masyarakat daerah Kabupaten Cianjur, dengan teknik random sampling. Kuesioner survey terdiri atas 7 pertanyaan identitas dan antropometri responden, dan 6 pertanyaan seputar persepsi dan aktivitas Ritmik yang biasa dilakukan oleh para responden. Pertanyaan yang diajukan menggunakan skala likert dari 1-5 poin untuk setiap pertanyaan.

Sampel responden terdiri atas 193 orang yang telah mengisi form secara online, terdiri atas responden dengan rentang usia 5-17 tahun dan 18-64 tahun. Data yang didapat dari form kuesioner tersebut kemudian diolah dengan menggunakan software statistic, untuk kemudian diproses dan diambil kesimpulan secara analisis deskriptif. Validitas daripada kuesioner di uji dengan menggunakan metode uji statistik product moment yang dapat dilihat pada tabel 1.

Table 1. Uji validitas kuesioner

\begin{tabular}{|c|c|c|c|c|c|c|c|}
\hline & $\begin{array}{c}\text { [Senam } \\
\text { SKJ] }\end{array}$ & $\begin{array}{c}\text { Senam } \\
\text { Aerobik } \\
\text { Low } \\
\text { impact }]\end{array}$ & $\begin{array}{c}\text { [Senam } \\
\text { Aerobik } \\
\text { High } \\
\text { impact }]\end{array}$ & $\begin{array}{c}\text { [Senam } \\
\text { Jantung } \\
\text { sehat / } \\
\text { lansia] }\end{array}$ & [Zumba] & $\begin{array}{c}\text { [Senam } \\
\text { dangdut] }\end{array}$ & $\begin{array}{l}\text { Total } \\
\text { Skor }\end{array}$ \\
\hline $\begin{array}{c}\text { Pearson } \\
\text { Correlation }\end{array}$ & 1 & $.453^{* *}$ & $.274^{* *}$ & $.467^{* *}$ & $.294^{* *}$ & $.339^{* *}$ & $.617^{* /}$ \\
\hline Sig. (2-tailed) & & 0.000 & 0.000 & 0.000 & 0.000 & 0.000 & 0.000 \\
\hline $\mathrm{N}$ & 192 & 192 & 192 & 192 & 192 & 192 & 192 \\
\hline
\end{tabular}

**. Correlation is significant at the 0.01 level (2-tailed).

Data yang diperoleh dalam penelitian ini merupakan data kuantitatif yang akan diubah menjadi data kualitatif. Data kuantitatif mengenai kualitas produk yang diperoleh dari para responden melalui kuesioner dengan Skala Likert dianalisis secara statistik deskriptif. Skala likert sendiri adalah skala pengukuran yang dikembangkan oleh Likert yang mempunyai empat atau lebih butir-butir pertanyaan yang dikombinasikan sehingga membentuk sebuah skor/nilai yang merepresentasikan sifat individu, misalkan pengetahuan, sikap, dan perilaku. Dalam proses analisis data, komposit skor, biasanya jumlah atau rataan, dari semua butir pertanyaan dapat digunakan. Penggunaan jumlah dari semua butir pertanyaan valid karena setiap butir pertanyaan adalah indikator dari variabel yang direpresentasikannya (Budiaji, 2013). 
Penilaian kualitas produk didasarkan pada hasil perhitungan konversi nilai dengan skala lima sebagaimana tertera pada table 2 .

Tabel 2. Hasil Konversi Data Kuantitatif ke Data Kualitatif

\begin{tabular}{ll}
\hline \multicolumn{1}{c}{ Interval skor } & \multicolumn{1}{c}{ Kriteria } \\
\hline $\mathrm{X}>4,21$ & Sangat baik \\
$3,40<\mathrm{X} \leq 4,21$ & Baik \\
$2,60<\mathrm{X} \leq 3,40$ & Cukup baik \\
$1,79<\mathrm{X} \leq 2,60$ & Kurang baik \\
$\mathrm{X} \leq 1,79$ & Sangat kurang baik \\
\hline
\end{tabular}

\section{HASIL}

Hasil daripada penelitian ini adalah gambaran aktivitas olahraga berbasis ritmik yang didapat berdasarkan perhitungan statistik deskriptif. Dari 193 responden yang mengisi angket, terdapat jumlah responden dengan jenis kelamin laki-laki sebanyak $44 \%$ responden dan perempuan sebanyak $56 \%$ responden.

Tabel 3. Jenis Kelamin Responden

\begin{tabular}{clr|r|r|r} 
& & Frequency & Percent & Valid Percent & $\begin{array}{c}\text { Cumulative } \\
\text { Percent }\end{array}$ \\
\hline Valid & Laki - laki & 85 & 44.0 & 44.0 & 44.0 \\
\cline { 2 - 6 } & Perempuan & 108 & 56.0 & 56.0 & 100.0 \\
\cline { 2 - 6 } & Total & 193 & 100.0 & 100.0 & \\
\hline
\end{tabular}

Berdasarkan perhitungan tabulasi silang pada tabel 3, responden berjenis kelamin lakilaki terdapat $4.7 \%$ responden bekerja di rumah, $27.1 \%$ bekerja sebagai pegawai kantor, dan $68.2 \%$ bekerja di luar kantor/ ruangan, sedangkan untuk responden berjenis kelamin perempuan terdapat $11.1 \%$ bekerja di rumah, $27.8 \%$ bekerja sebagai pegawai kantor, dan $61.1 \%$ bekerja di luar ruangan.

Tabel 4 menjelaskan informasi mengenai rentang usia yang responden terdiri atas $92 \%$ responden dengan usia rentang 18-64 tahun, dan $7,2 \%$ responden dengan rentang usia 5-17 tahun.

Tabel 4 . Rentang usia responden

\begin{tabular}{lcccc}
\hline & Freq & Percent & $\begin{array}{c}\text { Valid } \\
\text { Percent }\end{array}$ & $\begin{array}{c}\text { Cumulative } \\
\text { Percent }\end{array}$ \\
\hline $\begin{array}{l}5-17 \\
\text { tahun }\end{array}$ & 15 & 7.8 & 7.8 & 92.2 \\
$\begin{array}{l}18-64 \\
\text { tahun }\end{array}$ & 178 & 92.2 & 92.2 & 100 \\
Total & 193 & 100 & 100 & \\
\hline
\end{tabular}

Tabel 5 menginformasikan hasil survei mengenai persepsi responden laki-laki terhadap aktivitas ritmik, dimana responden laki - laki memiliki rata-rata ketertarikan 3.31 untuk senam SKJ, 2.65 untuk Senam Aerobik Low Impact, 2.69 untuk senam aerobic High Impact, 2.62 untuk senam Jantung Sehat/ Lansia, 2.48 untuk Zumba, dan 2.86 untuk senam Dangdut.

Tabel 5. Persepsi responden laki-laki

\begin{tabular}{lcccccc}
\hline & $\begin{array}{c}\text { Senam } \\
\text { SKJ }\end{array}$ & $\begin{array}{c}\text { Senam Aerobik } \\
\text { Low impact }\end{array}$ & $\begin{array}{c}\text { Senam Aerobik } \\
\text { High impact }\end{array}$ & $\begin{array}{c}\text { Senam Jantung } \\
\text { sehat / lansia }\end{array}$ & Zumba & Senam dangdut \\
\hline $\mathrm{N}$ & 85 & 85 & 85 & 85 & 85 & 84 \\
Valid Missing & 0 & 0 & 0 & 0 & 0 & 1 \\
Mean & 3.31 & 2.65 & 2.69 & 2.62 & 2.48 & 2.86 \\
Median & 3.00 & 3.00 & 3.00 & 3.00 & 3.00 & 3.00 \\
Mode & 3 & 3 & 2 & 2 & 3 & 3 \\
Std. Deviation & 1.000 & 1.110 & 1.080 & 1.080 & 1.140 & 1.204 \\
\hline
\end{tabular}

Tabel 6 menjabarkan persepsi responden perempuan terhadap aktivitas ritmik memiliki rata-rata 3.15 untuk senam SKJ, 2.91 untuk Senam Aerobik Low Impact, 2.88 untuk senam aerobic High Impact, 2.80 untuk senam Jantung
Sehat/ Lansia, 3.03 untuk Zumba, dan 2.94 untuk senam Dangdut.

Grafik 1 memberikan informasi mengenai tingkat rerata persepsi responden laki - laki dan perempuan terhadap aktivitas ritmik secara umum. Menurut Analisa deskriptif yang 
diperoleh dapat disimpulkan bahwa rata - rata responden perempuan memiliki persepsi yang lebih baik terhadap aktivitas ritmik dibanding responden laki - laki, terutama pada aktivitas berirama Senam Low Impact, Senam High
Impact, Senam Lansia, Senam Zumba, dan Senam Dangdut, sedangkan responden laki - laki memiliki persepsi yang lebih positif pada senam kesegaran jasmani.

Tabel 6. Partisipasi Responden Perempuan

\begin{tabular}{lcccccc}
\hline & $\begin{array}{c}\text { Senam } \\
\text { SKJ }\end{array}$ & $\begin{array}{c}\text { Senam Aerobik } \\
\text { Low impact }\end{array}$ & $\begin{array}{c}\text { Senam Aerobik } \\
\text { High impact }\end{array}$ & $\begin{array}{c}\text { Senam Jantung } \\
\text { sehat / lansia }\end{array}$ & Zumba & Senam dangdut \\
\hline $\mathrm{N}$ & 107 & 107 & 107 & 107 & 108 & 107 \\
Valid Missing & 1 & 1 & 1 & 1 & 0 & 1 \\
Mean & 3.15 & 2.91 & 2.88 & 2.80 & 3.03 & 2.94 \\
Median & 3.00 & 3.00 & 3.00 & 3.00 & 3.00 & 3.00 \\
Mode & 3 & 3 & 3 & 3 & 3 & 3 \\
Std. Deviation & .960 & .896 & 1.016 & 1.023 & 1.164 & 1.316 \\
\hline
\end{tabular}

Grafik 1. Rerata persepsi responden terhadap aktivitas ritmik

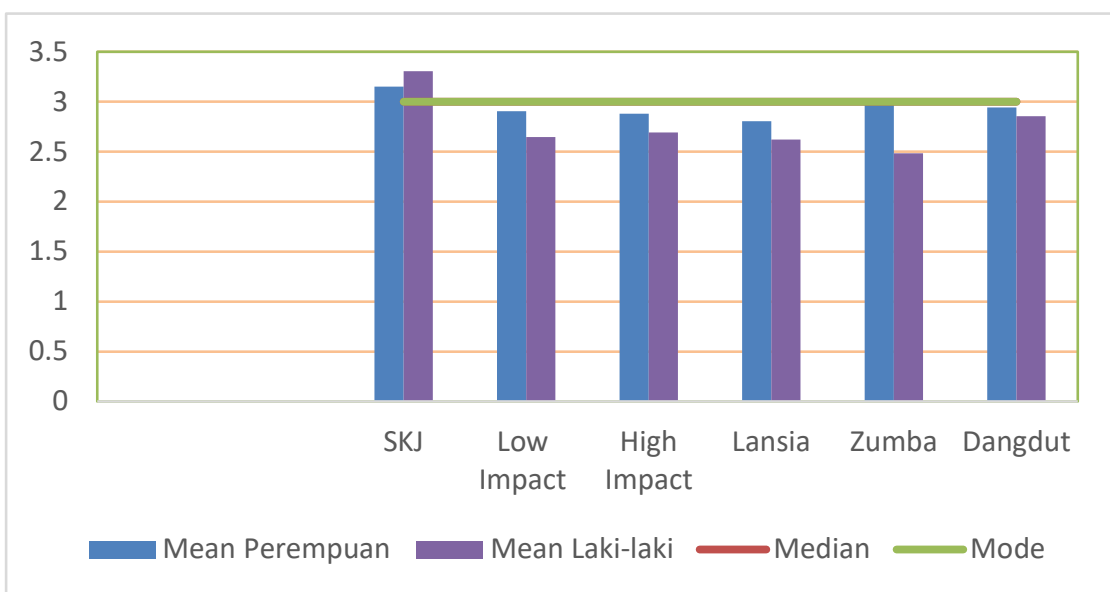

Berdasarkan grafik 2 bahwa, rerata responden baik laki - laki maupun perempuan bervariasi terhadap kemampuan mengajar instruktur. Dimana responden laki - laki lebih mengutamakan penampilan instruktur dibandingkan kemampuan gerakan, berbanding terbalik dengan persepsi responden perempuan yang lebih mengutamakan bentuk gerakan instruktur dibandingkan penampilannya. Kedua sample responden memiliki persepsi yang tidak jauh berbeda untuk komponen cara mengajar instruktur, dimana rerata responden perempuan memiliki persepsi yang lebih baik sedikit dibandingkan responden laki - laki. 
Grafik 2. Rerata Persepsi responden terhadap instruktur

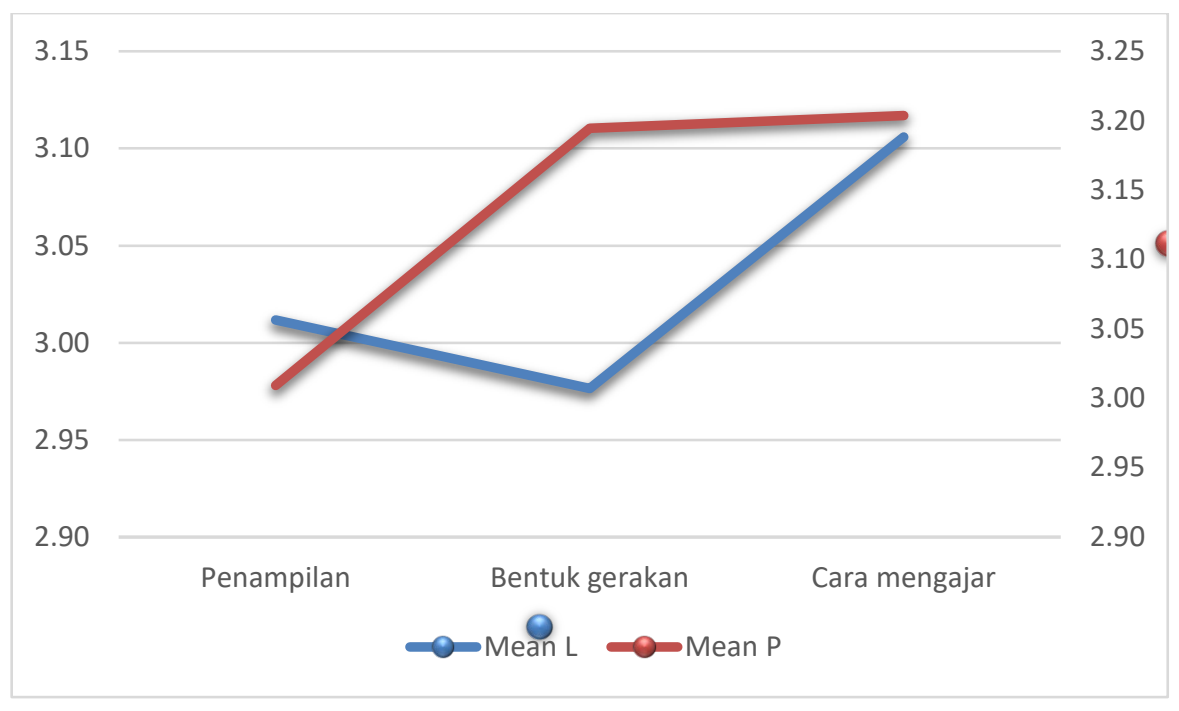

\section{PEMBAHASAN}

Hasil penelitian ini memberikan gambaran akan persepsi masyarakat terhadap kegiatan aktivitas jasmani yang bersifat ritmik yang cukup bervariasi, dimana rata-rata responden perempuan lebih menyukai aktivitas fisik ritmik dibandingkan responden laki-laki pada kategori aktivitas senam low-impact, senam high-impact, senam lansia, Zumba, dan senam dangdut, sedangkan rata-rata responden laki-laki lebih menyukai senam SKJ dibanding responden perempuan. Berdasarkan hasil yang didapat dari penelitian ini, maka dapat peneliti memberikan beberapa rekomendasi untuk dilakukan sebagai tindak lanjut dari pada penelitian ini, yakni; Tingkat persepsi aktivitas ritmik yang direspon oleh masyarakat masih dibawah rata-rata, hal ini dapat dikarenakan belum meratanya aktivitas fisik ritmik yang selama ini sudah dilakukan, kualitas instruktur juga sedikit mempengaruhi perbedaan persepsi diantara responden laki-laki dan perempuan, dimana responden perempuan memiliki persepsi yang lebih tinggi daripada responden laki-laki terhadap instruktur aktivitas ritmik.

Analisa deskriptif dari data hasil penelitian yang telah dilakukan, dapat disimpulkan beberapa hal sebagai berikut; Baik responden laki-laki maupun perempuan, memiliki pekerjaan di luar ruangan dengan sampel lebih banyak dibandingkan yang bekerja dalam ruangan/ kantor, data ketertarikan untuk melakukan aktivitas ritmik secara umum masih dibawah median 3.0 meski ada beberapa aktivitas ritmik yang cukup disukai bagi para responden. Responden laki-laki lebih menyukai Senam SKJ dibandingkan aktivitas ritmik yang lainnya, sedangkan untuk responden perempuan, senam SKJ dan Zumba dirasakan lebih menarik dengan skor rerata diatas nilai tengah. Meski demikian ketertarikan rata-rata responden laki-laki terhadap aktivitas ritmik secara umum masih dalam kategori "Cukup baik" menurut konversi data dengan norma kuantitatif-kualitatif, hanya respon untuk senam Zumba yang memiliki kategori "Kurang". Data responden perempuan menunjukkan tingkat ketertarikan untuk semua aktivitas ritmik dalam kategori "cukup baik". Rata-rata keseluruhan responden perempuan menunjukkan ketertarikan yang lebih baik terhadap aktivitas ritmik dibandingkan responden laki-laki, dan responden perempuan menunjukkan nilai rerata yang lebih tinggi dibandingkan responden lakilaki dalam tingkat persepsi terhadap instruktur aktivitas ritmik.

Meskipun tingkat partisipasi laki-laki lebih banyak dalam hal aktivitas fisik 
dibandingkan perempuan, ternyata hal tersebut berbeda dengan hasil yang didapat pada penelitian ini, dimana untuk aktivitas fisik yang menggunakan birama, responden perempuan justru memiliki persepsi dan keterlibatan yang lebih baik dibandingkan responden laki-laki.

Menurut penelitian yang telah dipublikasikan sebelumnya disebutkan bahwa senam aerobic dapat menurunkan kadar lemak tubuh secara efisien jika dibarengi dengan persepsi yang baik (Rifki, 2020). Sumber yang lain pun menyebutkan adanya hubungan yang positif antara kemampuan Intelligence Quotient terhadap pencapaian keterampilan dan prestasi olahraga senam (Widanita, Sukamti, \& Festiawan, 2020), dan tujuan masyarakat dalam melaksanakan aktivitas olahraga salah satunya adalah untuk bersenang-senang dan mendapat kegembiraan (Putra, 2020).

\section{KESIMPULAN}

Rerata responden baik laki - laki maupun perempuan bervariasi terhadap kemampuan mengajar instruktur. Responden laki - laki lebih mengutamakan penampilan instruktur dibandingkan kemampuan gerakan, sedangkan responden perempuan yang lebih mengutamakan bentuk gerakan.

Persepsi masyarakat mengenai aktivitas fisik berirama perlu dikaji secara lebih jauh guna mengetahui tingkat persepsi masyarakat umum dengan segmentasi yang lebih detail terhadap aktivitas fisik berirama yang sudah dikenal di masyarakat. Hal ini dapat membuka opsi aktivitas fisik yang dapat dilakukan dan diminati oleh masyarakat sebagai bagian dari usaha peningkatan kebugaran fisik masyarakat umum dengan metode aktivitas fisik yang positif dan beragam.

Mitos yang selama ini beredar di masyarakat bahwa masyarakat yang berjenis kelamin laki-laki lebih menyukai aktivitas fisik harus lebih diperdalam kembali dengan penelitian dan metode aktivitas tertentu yang mungkin menarik dari sudut pandang jenis kelamin dan rentang usia yang relevan.

\section{UCAPAN TERIMAKASIH}

Peneliti menghaturkan banyak terimakasih kepada rekan dosen dan para mahasiswa beserta semua responden yang berkontribusi kepada keberhasilan penelitian ini.

\section{REFERENSI}

Budiaji, W. (2013). LIKERT ( The Measurement Scale and The Number of Responses in Likert Scale ). 2(2), 127-133.

ÇAĞLAR, E., \& AŞÇI, FH, (2006). Gender and physical activity level differences in physical self-perception of university students: A case of Turkey. INTERNATIONAL JOURNAL OF SPORT PSYCHOLOGY, vol. 37, 58-74.

Juliasti, E., Kuswari, M., \& Jus'at, I. (2020). Senam irama lagu gizi seimbang meningkatkan kebugaran pada anak sekolah. Journal Sport Area, 5, 22-29. https://doi.org/https://doi.org/10.25299 /sportarea.2020.vol5(1).4053

Lane, A. M. (2008). Sport and Exercise Psychology (1st ed.). Retrieved from www.hoddereducation.com

Lin, Y. (2014). Exploration of Teaching Modes of Children Creative Rhythmic Activities. (Icssr), 919-922. https://doi.org/10.2991/icssr-14.2014.202

Lucy Oktavani, A. M. (2017). Pengaruh Senam Skj 2008 Terhadap Kebugaran Jasmani Siswi Sekolah Dasar Negeri 20 Alang Laweh Padang Selatan Kota Padang. Journal Sport Area, 8(9), 1-58. https://doi.org/10.1017/CBO9781107415 324.004

Lykesas, G., Dania, A., Koutsouba, M., \& Nikolaki, E. (2017). The Effectiveness of a Music and Movement Program for Traditional Dance Teaching on Primary School Students ' Intrinsic Motivation and Self -Reported Patterns of Lesso .... (January). https://doi.org/10.5901/mjss.2017.v8n1p 227

Ministry of Health Republic of Indonesia. (2013). Strategic Planning Ministry of Health 2015-2019. Ministry of Health RI, 28(2), 8-9. Retrieved from http://p2048www.liberty.edu.ezproxy.liberty.edu:2048 
/login?url=http://search.proquest.com.ez proxy.liberty.edu:2048/docview/1352763 280? accountid $=12085 \% 5 \mathrm{Cn}$

Ministry of Health RI. (2018). Indonesia Health Profile 2017 Ministry of Health of the Republic of Indonesia 2018. Retrieved from

http://www.depkes.go.id/resources/dow nload/pusdatin/profil-kesehatanindonesia/indonesia-health-profile2017.pdf

Nahrawi, I. (2017). Rencana Strategis Kementrian Pemuda dan Olahraga (Strategic Planning of Ministry of Youth and Sport).

Penyusun, K. B. I. (n.d.). Kamus Besar Bahasa Indonesia (T. Penyusun, ed.). Jakarta: Pusat Bahasa.

Putra, M. F. P. (2020). Bagaimana Motivasi Olahraga Mahasiswa di Papua? Jurnal Terapan Ilmu Keolahragaan, 5(1), 51-60. https://doi.org/10.17509/jtikor.v5i1.2441 5

Soraya, N. (2012). Perbandingan Senam Aerobik Mix Impactdengan Senam Skj 2012 Dan Motivasi Berprestasi Terhadap Daya Tahan Cardiorespiratory. Journal Sport Area, 63(3), 63-75. https://doi.org/https://doi.org/10.25299 /sportarea.2017.vol2(2).878

Stott, R. (2013). Physical education. Architectural Review, (1394), 30. https://doi.org/10.4324/978131551769845

Suharjana, F. (2010). Aktivitas Ritmik Dalam Pendidikan Jasmani Di Sekolah Dasar. Jurnal Pendidikan Jasmani Indonesia, 116.

T. Armstrong, A. Bauman, F. Bull, V. Candeias, M. Lewicka, C. Magnussen, A. Persson, S. S. (2007). A guide for population-based approaches to increasing levels of physical activity: implementation of the WHO Global Strategy on Diet, Physical Activity and Health. In World Health Organization. Geneva: WHO Press.

Terry, P. C., \& Karageorghis, C. (2006). Psychophysical Effects of Music in Sport and Exercise: An Update on Theory, Research and Application. The Sport
Journal, 415-419. Retrieved from http://www.thesportjournal.org/article/ music-sport-and-exercise-update-researchand-application

Waters, S., \& McPherson, G. E. (2014). Facilitators and impediments for elective music and sport in adolescent males. SAGE Open, 4(2). https://doi.org/10.1177/21582440145297 79

Widanita, N., Sukamti, E. R., \& Festiawan, R. (2020). Hubungan Tingkat Intelligence Qoutient (IQ) dan Bakat dengan Hasil Kejuaraan Senam POPDA DIY. Jurnal Terapan Ilmu Keolahragaan, 5(1), 41-50. https://doi.org/10.17509/jtikor.v5i1.2446 3

World Health Organization. (2020). WHO Guidelines on physical activity and sedentary behaviour for children and adolescents, adults and older adults. Draft for Consultation Only, (March), 1-34.

Yudho, F. (2016). A Correlation of selfconfidence with skill abilities of basic gymnastics movements on Students of PJKR FKIP Suryakancana University. 1(Physical Education), 14-20. Retrieved from

https://scholar.google.com/scholar?oi=bi bs\&cluster $=16434520109193772292 \& b t n I$ $=1 \& \mathrm{hl}=\mathrm{en}$

Yudho, F. (2018). Analisis keterampilan gerak dan ritmik pada mahasiswa pendidikan jasmani fkip universitas suryakancana. 02(01), 23-29. https://doi.org/https://doi.org/10.31605 /ijes.v2i1

Yudho, F., Taufik, M., \& Afriyuandi, A. (2020). Analisis Kebiasaan Merokok Terhadap Pencapaian Pembelajaran Mata Pelajaran Di Sekolah. 9(1), 64-72. https://doi.org/https://doi.org/10.36706 /altius.v9i1.11583 